\title{
IMPLEMENTASI PENDEKATAN STUDENT CENTERED LEARNING DALAM PEMBELAJARAN IPA DAN RELEVANSINYA DENGAN HASIL BELAJAR SISWA KELAS VIII SMP NEGERI 4 SINGARAJA
}

\author{
Kadek Tenova Satriaman, Ni Made Pujani, Putri Sarini \\ PROGRAM STUDI S1 PENDIDIKAN IPA \\ UNIVERSITAS PENDIDIKAN GANESHA \\ SINGARAJA, INDONESIA
}

e-mail: \{tenova.satriaman, made.pujani, putri.sarini\}@undiksha.ac.id

\begin{abstract}
Abstrak
Penelitian ini bertujuan untuk mendeskripsikan implementasi pendekatan student centered learning (SCL) dalam pembelajaran IPA, faktor-faktor yang memengaruhi implementasi pendekatan SCL, dan relevansi pendekatan SCL dengan hasil belajar siswa. Penelitian ini termasuk penelitian deskriptif-kualitatif. Subjek dalam penelitian ini adalah 1 orang kepala sekolah, 5 orang guru IPA dan 90 orang siswa kelas VIII. Teknik pengambilan sampel dilakukan dengan purposive sampling. Metode pengumpulan data yang digunakan observasi, wawancara, dan studi dokumen. Teknik analisis data yang dilakukan dengan 4 tahapan yaitu pengumpulan data, reduksi data, penyajian data dan penarikan kesimpulan. Hasil penelitian menunjukkan bahwa: (1) Implementasi pendekatan SCL berkategori baik meskipun belum sepenuhnya dapat diterapkan. (2) Faktor-faktor yang memengaruhi implementasi pendekatan SCL adalah kemampuan guru dan sarana prasarana belajar. (3) Implementasi pendekatan SCL berhubungan erat dengan hasil belajar IPA siswa. Pembelajaran berbasis pendekatan SCL dapat diterapkan dengan menggunakan metode pembelajaran inovatif.
\end{abstract}

Kata kunci: implementasi pendekatan student centered learning, hasil belajar

\section{Abstract}

This study aims to describe the implementation of student centered learning (SCL) approach in science learning, factors influencing the implementation of SCL approach, and the relevance of SCL approach to student learning outcomes. This research includes descriptive-qualitative research. Subjects in this study were 1 headmaster, 5 science teachers and 90 class VIII students. The sampling technique is done by purposive sampling. Data collection methods used observation, interviews, and document studies. Data analysis techniques performed with 4 stages of data collection, data reduction, data presentation and drawing conclusions. The results showed that: (1) The implementation of SCL approach is categorized well although not yet fully applicable. (2) The factors that influence the implementation of the SCL approach are the ability of teachers and learning infrastructure. (3) The implementation of SCL approach is closely related to students' learning outcomes. SCL-based learning approaches can be applied using innovative learning methods.

Keywords: implementation of student centered learning approach, learning outcomes

\section{PENDAHULUAN}

Pembelajaran IPA Terpadu adalah pembelajaran IPA dengan situasi lebih alami dan situasi dunia nyata, serta mendorong siswa membuat hubungan antara cabang IPA yaitu fisika, kimia, dan biologi (Depdiknas, 2006). Pembelajaran IPA terpadu dianjurkan untuk diaplikasikan pada jenjang/tingkat Sekolah Menengah $\begin{array}{llr}\text { Pertama } & \text { /Madrasah } & \text { Tsanawiyah } \\ \text { (SMP/MTs). } & \text { Pembelajaran } & \text { ini pada }\end{array}$ hakikatnya merupakan suatu pendekatan pembelajaran yang memungkinkan siswa aktif mencari, menggali, dan menemukan konsep serta prinsip yang dipelajari secara menyeluruh (holistik), bermakna, otentik dan aktif (Depdikbud, 1996). 
Pembelajaran kurikulum 2013 menerapkan pendekatan SCL sebagai salah satu pendekatan pembelajaran dalam bidang pendidikan. Pendekatan ini memberikan kebebasan dan fasilitas kepada siswa untuk menggali sendiri ilmu pengetahuannya sehingga akan didapatkan pengetahuan yang mendalam (deep learning) dan mampu meningkatkan kualitas siswa. Karsen (2008) menyatakan bahwa melalui penerapan pembelajaran yang berpusat pada siswa, maka siswa diharapkan dapat berpartisipasi secara aktif, selalu ditantang untuk memiliki daya kritis, mampu menganalisa dan dapat memecahkan masalahnya sendiri. Pembelajaran berpusat pada siswa (student centered learning) merupakan suatu pembelajaran yang menempatkan siswa sebagai pusat dari proses belajar. Pembelajaran berpusat pada siswa berbeda dari pembelajaran berpusat pada guru (teacher centered learning) yang menekankan transfer pengetahuan dari guru ke siswa yang relatif bersifat pasif. Pendekatan pembelajaran berpusat pada siswa merupakan pembelajaran aktif dimana siswa memecahkan masalah, menjawab pertanyaan, merumuskan pertanyaan mereka sendiri, berdiskusi, menjelaskan selama di kelas, pembelajaran kooperatif, dimana siswa bekerja dalam tim pada masalah dan proyek.

Pembelajaran yang menggunakan kurikulum 2013 wajib menerapkan pendekatan SCL pada semua mata pelajaran, termasuk juga mata pelajaran IPA (Kemendikbud, 2013). Implementasi kurikulum 2013 pada pembelajaran IPA dikembangkan sebagai mata pelajaran IPA terpadu (integrative science), bukan mata pelajaran yang terpisah sesuai dengan disiplin ilmu. Ilmu Pengetahuan Alam (IPA) berkaitan dengan cara mencari tahu tentang alam secara sistematis, sehingga IPA bukan hanya penguasaan kumpulan pengetahuan yang berupa fakta-fakta, konsep-konsep, atau prinsip-prinsip saja tetapi juga merupakan suatu proses penemuan (Badan Standar Nasional Pendidikan, 2006). Pembelajaran IPA dilaksanakan secara terpadu karena melalui pembelajaran IPA terpadu siswa dapat memperoleh pengalaman langsung, sehingga dapat menambah kekuatan untuk mencari, menyimpan dan menerapkan konsep yang telah dipelajarinya.

Sesuai dengan kurikulum 2013 di SMP, guru IPA perlu mendorong siswa agar terlibat aktif dalam proses pembelajaran. Hal ini bertujuan agar siswa tersebut dapat memperoleh pengalaman belajar secara langsung sehingga dapat meningkatkan hasil belajar. Berdasarkan Permendikbud No. 103 tentang pembelajaran pada Pendidikan Dasar dan Menengah Tahun 2014 menyatakan bahwa guru memfasilitasi siswa untuk melakukan proses mengamati, menanya, mengumpulkan informasi, menalar/mengasosiasi,

dan mengomunikasikan adalah tahapantahapan pembelajaran kurikulum 2013 dengan pendekatan saintifik yang merupakan pembelajaran berpusat pada siswa. Hal tersebut menyatakan guru berperan sebagai fasilitator dan siswa yang berperan aktif dalam kegiatan pembelajaran di sekolah.

Berdasarkan Permendikbud No. 81A tentang implementasi kurikulum 2013, sekolah diwajibkan untuk menggunakan pendekatan SCL. Namun, masih banyak sekolah yang sudah menggunakan kurikulum 2013 tetapi belum menerapkan pendekatan SCL, termasuk di SMP Negeri 4 Singaraja. Berdasarkan observasi awal dan wawancara dengan pihak guru guru mata pelajaran IPA di SMP Negeri 4 Singaraja, diperoleh fakta bahwa pendekatan SCL belum sepenuhnya diterapkan. Bahkan, ada beberapa guru yang mengaku belum memahami kurikulum 2013 meskipun telah mengikuti kegiatan pelatihan guru untuk mengimplementasikan kurikulum 2013. Dampaknya ada beberapa guru masih menggunakan pendekatan teacher centered yang berpotensi pada makin rendahnya kualitas pembelajaran di sekolah.

Berdasarkan hasil survei TIMSS (Trend Internasional Mathematics and Science Study), tingkat kualitas pendidikan di Indonesia dari tahun ke tahun terus menurun. Pada tahun 2011 Indonesia menduduki peringkat 40 dari 42 negara 
yang berpartisipasi (Balitbang, 2011), sedangkan prestasi literasi IPA pada PISA (Programme for International Student Assessment) tahun 2012, Indonesia menempati urutan 64 dari 65 negara, dibawah Qatar dan di atas Peru. Dengan rata-rata skor untuk pelajaran sains adalah 385, padahal rata-rata skor OECD (Organization for Economic Coorporation dan Development) adalah 501 (OECD, 2014).

Kecenderungan pendidik menerapkan pendekatan pembelajaran berpusat pada guru yang menjadi salah satu penyebab menurunnya kualitas pendidikan di Indonesia. Walaupun untuk beberapa kondisi kegiatan belajar mengajar, teacher centered sebenarnya sudah cukup baik. Namun ketika harus berhadapan dengan kondisi siswa yang berbeda-beda karakternya, maka pa-radigma ini sudah tidak bijak lagi untuk tetap diterapkan (Brown, 2003).

Hal Ini menunjukkan bahwa perubahan paradigma tersebut belum sepenuhnya mampu meningkatkan hasil belajar siswa secara maksimal. Sebagai contoh, pembelajaran yang menggunakan metode diskusi kelompok, siswa cenderung tidak fokus terhadap materi yang disampaikan oleh guru, bahkan siswa lebih banyak menghabiskan waktu untuk membicarakan tentang "dunia" mereka, dari pada untuk memahami materi yang diberikan (Isjoni, 2007). Jika terus seperti ini pada proses pembelajaran, maka dikhawatirkan tujuan pembelajaran tidak tercapai secara maksimal, dan pada akhirnya akan memengaruhi hasil belajar siswa. Hasil belajar yang kurang maksimal ini ditunjukkan dengan nilai hasil belajar ranah kognitif IPA siswa kelas VIII di SMP Negeri 4 Singaraja yang masih belum mencapai standar Kriteria Kelulusan Minimal (KKM), yaitu 72. Berdasarkan hasil ulangan akhir semester (UAS) semester gasal tahun pelajaran 2016/2017 yang peneliti peroleh dari salah satu guru yang mengajar mata pelajaran IPA di kelas VIII B4 yang berjumlah 37 siswa, VIII B5 berjumlah 35 siswa dan VIII B6 berjumlah 37 siswa untuk mata pelajaran IPA nilai siswa masih di bawah KKM. Dari 3 kelas tersebut, siswa yang memperoleh nilai di atas KKM ada 15 siswa dari 109 siswa atau dapat dikatakan siswa yang tuntas hanya $13,76 \%$. Bertolak dari data hasil belajar berupa nilai ulangan akhir semester tersebut maka, untuk dapat meningkatkan kualitas pendidikan di Indonesia maka perlu di-lakukan pengkajian secara mendalam mengenai implementasi pendekatan SCL di sekolah.

\section{METODE}

Metode penelitian yang digunakan adalah metode deskriptif-kualitatif. Hal ini dimaksudkan agar peneliti dapat membuat analisis deskriptif secara sistematis, faktual dan akurat dalam mengungkapkan fakta mengenai implementasi pendekatan SCL dalam pembelajaran IPA.

Subjek dalam penelitian ini adalah 1 orang kepala sekolah, 5 orang guru IPA dan 90 orang siswa kelas VIII tersebar dari 10 kelas yang memiliki kriteria nilai raport tinggi, sedang, dan rendah, sedangkan objek dalam penelitian ini adalah implementasi pendekatan SCL dalam pembelajaran IPA, faktor-faktor yang memengaruhi implementasi pendekatan SCL dan relevansinya terhadap hasil belajar siswa.

Sumber data yang akan dikumpulkan dalam penelitian ini dikelompokkan menjadi dua, yaitu sumber data primer dan sumber data sekunder. Sumber data primer, yaitu data yang langsung dikumpulkan peneliti dari sumber pertamanya. Adapun yang menjadi sumber data primer dalam penelitian ini adalah kepala sekolah, guru IPA dan siswa kelas VIII. Sumber data sekunder, yaitu data yang langsung dikumpulkan peneliti sebagai penunjang dari sumber pertama pihak pertama. Dapat juga data yang tersusun dalam bentuk dokumen.

Teknik pengambilan sampel dilakukan dengan purposive sampling. Penentuan sampel dalam penelitian kualitatif tidak didasarkan perhitungan statistik. Hasil penelitian tidak akan digeneralisasikan ke populasi karena, pengambilan sampel tidak secara random (Sugiyono, 2015). Metode pengumpulan data yang digunakan dengan pedoman observasi, wawancara, dan studi dokumen. 
Analisis data penelitian ini adalah analisis data kualitatif dan kuantatif. Analisis data kualitatif untuk mengetahui persentase hasil observasi mengenai pendekatan SCL. Miles dan Huberman (Sugiyono, 2015) menyatakan bahwa dalam analisis data terdapat 4 komponen yang dilakukan yaitu: pengumpulan data, reduksi data, penyajian data dan penarikan kesimpulan. Teknik analisis data kuantitatif digunakan untuk mengetahui relevansi implementasi pendekatan SCL terhadap hasil belajar IPA siswa ditinjau dari ranah kognitif.

\section{HASIL DAN PEMBAHASAN}

\section{Implementasi Pendekatan SCL}

Berdasarkan observasi yang dilakukan peneliti, secara keseluruhan pembelajaran yang dilakukan guru model sudah mencerminkan adanya penerapan aspek-aspek pendekatan student centered learning. Selama pembelajaran aktivitas lebih didominasi dengan kegiatan yang dilakukan oleh siswa. Pada awal pembelajaran guru membuka pembelajaran dengan me-ngucapkan salam dan mengkondisikan siswa agar siap mengikuti pembelajaran. Setelah semua siswa terkondisikan, guru memberikan apersepsi dengan melakukan tanya jawab dengan siswa secara menyeluruh terkait dengan pengalaman disekitar siswa sehingga dapat menarik siswa untuk berpartisipasi aktif dalam memulai pembelajaran. Siswa tampak antusias memberikan jawaban atas pertanyaan yang diberikan guru. Mengawali pembelajaran guru memberitahu siswa materi yang diajarkan pada pertemuan kali ini. Metode mengajar yang digunakan adalah menjelaskan materi, diskusi kelompok, dan percobaan. Pertama-tama guru menjelaskan materi yang dipelajari guna memberikan gambaran awal pada siswa. Setelah menyampaikan materi guru menanyakan pada siswa materi yang belum dipahami. Jika dirasa siswa sudah paham materi yang diberikan, maka guru mengajak siswa melakukan percobaan sederhana yang didiskusikan dengan kelompok. Siswa terlihat antusias selama melakukan percobaan dan diskusi. Setelah melakukan percobaan, pada masing-masing kelompok diminta mempresentasikan hasil diskusi dari percobaan yang sudah dilakukan. Guru memberikan kesempatan pada kelompok lain untuk bertanya dari presentasi yang disampaikan kelompok penyaji. Selanjutnya, guru memberikan sanggahan dari pertanyaan maupun saran yang diberikan siswa lain kepada kelompok penyaji. Pada akhir pembelajaran guru mengajak siswa untuk menyimpulkan pembelajaran yang sudah dilakukan.

Berdasarkan data hasil observasi guru model yang peneliti lakukan dengan menggunakan lembar pedoman observasi guru yang mengimplementasikan pendekatan SCL yang peneliti buat, dapat diketahui bahwa rata-rata skor yang diperoleh 20,55 dengan persentase ratarata skor sebesar $75,88 \%$. Ini menunjukkan bahwa pelaksanaan aktivitas guru termasuk dalam kategori baik. Sesuai observasi yang dilakukan peneliti terhadap guru model dari kegiatan pembelajaran yang dilakukan pada tiap kelas yang diajarkan sudah sesuai dengan karakteristik pendekatan SCL meskipun beberapa indikator belum maksimal di-lakukan oleh guru.

Skor rata-rata observasi guru model yang mengimplementasikan pendekatan SCL di SMP Negeri 4 Singaraja disajikan pada Tabel 4.1 berikut.

Tabel 4.1 Skor rata-rata observasi guru yang mengimplementasikan pendekatan SCL

\begin{tabular}{cccc}
\hline Guru Model & Rata-rata & Nilai & Kategori \\
1 & 20 & 74 & Baik \\
2 & 19,5 & 72,2 & Baik \\
3 & 21,75 & 79,6 & Baik \\
4 & 20,75 & 76,8 & Baik \\
5 & 20,75 & 76,8 & Baik \\
\hline
\end{tabular}

Sejalan dengan observasi yang peneliti lakukan terhadap guru, peneliti juga memperoleh data berdasarkan perhitungan hasil observasi siswa mengenai implementasi pendekatan SCL dalam pembelajaran IPA.

Berdasarkan perhitungan hasil observasi siswa mengenai implementasi pendekatan SCL terhadap 30 siswa yang me-miliki nilai IPA tertinggi diseluruh kelas VIII sesuai raport diketahui bahwa rata-rata skor yang diperoleh 38,09 dengan 
persentase rata-rata skor sebesar $70,54 \%$. Hasil perhitungan ini menunjukkan bahwa pelaksanaan aktivitas belajar siswa termasuk dalam kategori baik. Dari observasi yang dilakukan peneliti terhadap 30 siswa tersebut, dalam pembelajaran yang dilakukan sudah sesuai dengan indikator dari instrumen observasi yang peneliti buat meskipun beberapa indikator belum dapat dicapai siswa secara maksimal. Indikator yang belum dicapai siswa secara maksimal dari aspek merumuskan harapan terhadap proses pembelajaran dan mengukur kinerjanya, memantau pembelajarannya sendiri, dan mengembangkan materi belajar secara mandiri.

Berdasarkan perhitungan hasil observasi siswa mengenai implementasi pendekatan SCL terhadap 30 siswa yang me-miliki nilai IPA sedang diseluruh kelas VIII sesuai raport diketahui bahwa rata-rata skor yang diperoleh 35,41 dengan persentase rata-rata skor sebesar $65,57 \%$. Ini menunjukkan bahwa pelaksanaan aktivitas belajar siswa termasuk dalam kategori baik. Dari observasi yang dilakukan peneliti terhadap 30 siswa tersebut, dalam pembelajaran yang dilakukan sudah sesuai dengan indikator dari instrumen observasi yang peneliti buat meskipun beberapa indikator belum dapat dicapai siswa secara maksimal. Indikator yang belum dicapai siswa secara maksimal dari aspek mampu sebagai tokoh yang aktif, mengembangkan materi belajar secara mandiri, merumuskan harapan terhadap proses pembelajaran dan mengukur kinerjanya, memantau pembelajarannya, dan membangun pengetahuannya sendiri.

Berdasarkan perhitungan hasil observasi siswa mengenai implementasi pendekatan SCL terhadap 30 siswa yang me-miliki nilai IPA rendah diseluruh kelas VIII sesuai raport diketahui bahwa rata-rata skor yang diperoleh 32,44 dengan persentase rata-rata skor sebesar $60,08 \%$. Ini menunjukkan bahwa pelaksanaan aktivitas belajar siswa termasuk dalam kategori baik. Dari observasi yang dilakukan peneliti terhadap 30 siswa tersebut, dalam pembelajaran yang dilakukan sudah sesuai dengan indikator dari instrumen observasi yang peneliti buat meskipun beberapa indikator belum dapat dicapai siswa secara maksimal. Indikator yang belum dicapai siswa secara maksimal dari aspek mampu sebagai tokoh yang aktif, mengembangkan materi belajar secara mandiri, merumuskan harapan terhadap proses pembelajaran dan mengukur kinerjanya, memantau pembelajarannya sendiri, membangun pengetahuannya sendiri, dan termotivasi untuk mencapai sasaran yang telah ditetapkannya sendiri.

Skor rata-rata observasi siswa mengenai implementasi pendekatan SCL ditinjau dari nilai raport siswa SMP Negeri 4 Singaraja disajikan pada Tabel 4.2 berikut.

Tabel 4.2 Skor rata-rata observasi siswa mengenai implementasi pendekatan student centered learning

\begin{tabular}{cccc}
\hline Kategori kemampuan & Rata-rata & $\%$ & Kategori \\
kognitif siswa & 38,09 & 70,54 & Baik \\
Tinggi & 35,41 & 65,57 & Baik \\
Sedang & 32,44 & 60,08 & Baik \\
Rendah & & & \\
\hline
\end{tabular}

Berdasarkan hasil wawancara menyatakan bahwa, SMP Negeri 4 Singaraja sudah menerapkan kurikulum 2013 sejak Tahun Pelajaran 2013/2014. Selama itu juga guru sudah menerapkan pendekatan pembelajaran SCL sampai sekarang ini. Menurut kepala sekolah, sebelum guru melaksanakan pembelajaran berbasis pendekatan SCL guru sudah menyiapkan RPP yang dibuat sendiri dengan bekerjasama di dalam forum MGMP. Selama guru me-nerapkan pendekatan SCL di dalam proses pembelajaran terkadang saat pelaksanaannya di kelas belum sepenuhnya dapat diterapkan sebab guru dihadapkan pada banyaknya kendala, baik itu dari sikap siswa dan kemampuan siswa 
yang berbeda-beda pada tiap kelas. Sejalan dengan itu, kepala sekolah juga mengatakan bahwa apa yang diharapkan tidak sesuai dengan kenyataan di lapangan. Orientasi pembelajaran dari pendekatan teacher centered ke student centered learning tentu ada hambatan-hambatannya dari sumber daya siswa itu sendiri, sumber daya yang masuk masih sangat kurang sehingga untuk me-nerapkan pendekatan ini masih belum bisa sepenuhnya dapat diterapkan. Dengan kemampuan siswa yang bervariasi ini diperlukan kejelian guru dalam menggunakan metode yang cocok diterapkan di kelas yang berbeda sehingga RPP yang dibuat guru tidak seragam, mungkin pendekatan SCL dapat diterapkan di kelas atas namun kelas bawah belum tentu sepenuhnya dapat diterapkan.

Dari analisis data mengenai pembelajaran IPA yang berpusat pada siswa (SCL) di kelas VIII SMP Negeri 4 Singaraja menunjukkan bahwa penerapan pembelajaran yang dilakukan dari guru dan siswa di-sesuaikan dengan karakteristik dari pendekatan SCL.

$$
\text { Pada tahap perencanaan }
$$

pembelajaran, sesuai dengan wawancara yang peneliti lakukan kepada kepala sekolah dan guru IPA yang mengajar di kelas VIII SMP Negeri 4 Singaraja menggunakan silabus yang telah dikembangkan oleh Kementerian Pendidikan dan Budaya (Kemdikbud) sebagai pedoman penyusunan rencana pelaksanaan pembelajaran (RPP). Kemudian, guru menyusun RPP secara mandiri dengan bekerjasama dalam forum MGMP IPA yang ada di sekolah disesuaikan dengan situasi dan kondisi sekolah. Ini di-sesuaikan dengan Permendikbud Nomor 65 Tahun 2013 tentang komponen RPP dan Permendikbud Nomor 81A Tahun 2013 tentang sistematika format RPP. RPP guru IPA kelas VIII SMP Negeri 4 Singaraja mencantumkan komponen RPP seperti materi pokok pembelajaran yang akan dibahas, tujuan pembelajaran dan media alat serta sumber belajar. Pada RPP dicantumkan KD berdasarkan $\mathrm{KI}-1, \mathrm{KI}-2, \mathrm{KI}-3$ dan $\mathrm{KI}-4$ serta memuat materi pelajaran berdasarkan fakta, konsep, prinsip dan prosedural. Pada penilaian guru IPA di SMP Negeri 4 Singaraja melaksanakan penilaian $\mathrm{KI}-1, \mathrm{KI}-$ 2 dan KI-4 yaitu penilaian kognitif (pengetahuan), afektif (sikap) dan psikomotor (keterampil-an) menggunakan rubrik penilaian. Penilaian pengetahuan dilakukan pada saat pemeriksaan tugas, ulangan harian, ulangan tengah semester (UTS), dan ulangan kenaikan kelas (UKK), penilaian sikap dilakukan guru selama proses pembelajaran di dalam kelas maupun di luar kelas secara berkala sebab jumlah siswa yang banyak guru kesulitan untuk menilai siswa sekaligus, dan penilaian keterampilan siswa biasanya dilakukan pada saat siswa melakukan praktikum/percobaan karena yang dinilai dari siswa adalah bagaimana dia mau melakukan praktikum dilihat dari keterampilan prosesnya.

Pada tahap pelaksanaan pembelajaran, sesuai dengan observasi yang peneliti lakukan selama aktivitas mengajar guru IPA menerapkan pembelajaran yang berpusat pada siswa yang menempatkan siswa sebagai pusat pembelajaran, khususnya dalam kegiatan inti pembelajaran yang dalam pelaksanaanya sesuai dengan alokasi waktu yang sudah ditentukan dalam RPP. Pada tahap pertama, guru mengarahkan siswa untuk membaca materi yang akan disampaikan oleh guru selama beberapa menit yang terdapat pada buku paket dan LKS. Kemudian pada tahap kedua, guru mengarahkan agar siswa mau bertanya dari apa yang sudah mereka baca sebelumnya dari materi tersebut. Setelah itu, guru menyampaikan materi yang akan dibahas pada pertemuan kali ini. Pada tahap ketiga, guru membagi siswa dalam bentuk kelompok yang bertujuan agar siswa bekerjasama mencari dan mengumpulkan informasi dari berbagai sumber dan berdiskusi untuk menjawab pertanyaan yang sudah guru siapkan sebelumnya. Pada tahap keempat, siswa secara berkelompok me-ngolah informasi yang sudah didapatkan melalui berbagai macam sumber kemudian dianalisis data tersebut sampai dapat menyimpulkan jawaban dari pertanyaan yang diberikan guru dibuat dalam bentuk laporan. Pada tahap kelima, 
siswa mempresentasikan hasil diskusi mereka kepada kelompok lainnya sehingga dapat terjadi proses tanya jawab dan diskusi antara kelompok penyaji dengan kelompok lainnya. Pada proses tanya jawab terlihat keantusiasan siswa kelompok penyaji dan juga kelompok lainnya, kelompok penyaji mendiskusikan pertanyaan yang diajukan siswa/kelompok lainnya, dan kelompok lain memberikan pertanyaan maupun saran kepada kelompok penyaji bila masih ada yang kurang dalam penyampaiannya. Pada kegiatan penutup, guru mengajak siswa untuk menyimpulkan materi yang sudah dibahas sebelumnya. Setelah itu, guru memberikan pekerjaan rumah kepada siswa dan menyuruh siswa untuk mempelajari materi yang akan dibahas pada pertemuan selanjutnya.

Berdasarkan observasi yang peneliti lakukan tersebut maka diperoleh perhitungan hasil observasi aktivitas guru, yang dapat dilihat pada hasil penelitian. Dari hasil perhitungan observasi tersebut, dapat diketahui bahwa dari observasi pertama sampai dengan observasi keempat guru model 1 penilaian terhadap aktivitas guru tidak terjadi perubahan dari metode yang guru gunakan saat mengajar dengan rata-rata skor 20 dan persentase skor sebesar $74 \%$. Guru model 2 penilaian terhadap aktivitas guru pada observasi pertama mendapat skor sebesar 18 dan mengalami peningkatan skor menjadi 20 pada observasi kedua, ketiga dan keempat. Dari keempat observasi tersebut diperoleh rata-rata skor 19,5 dan persentase skor sebesar $72,2 \%$. Guru model 3 penilaian terhadap aktivitas guru pada observasi pertama memperoleh skor sebesar 21 dan me-ngalami peningkatan pada observasi kedua, ketiga dan keempat menjadi 22. Dari keempat observasi tersebut diperoleh ratarata skor 21,75 dan persentase skor sebesar $79,6 \%$. Guru model 4 dan model 5 penilaian terhadap aktivitas guru pada observasi pertama memperoleh skor sebesar 20 dan mengalami peningkatan pada observasi kedua, ketiga dan keempat menjadi 21. Dari keempat observasi tersebut diperoleh rata-rata skor 20,75 dan persentase skor sebesar $76,8 \%$. Setelah dilakukan perhitungan, rata-rata skor diperoleh 20,55 dengan persentase ratarata skor sebesar 75,88\% menunjukkan bahwa pelaksanaan aktivitas guru termasuk dalam kategori baik.

Selain melakukan observasi pada guru, peneliti juga melakukan observasi terhadap aktivitas belajar siswa sehingga diperoleh hasil perhitungan observasi sesuai yang peneliti buat pada hasil penelitian. Dari sepuluh kelas VIII yang ada, peneliti memilih sembilan siswa pada setiap kelas yang ada dilihat dari nilai raport mata pelajaran IPA terdiri dari 3 siswa yang memiliki nilai yang tinggi, 3 siswa yang memiliki nilai sedang dan 3 siswa yang memiliki nilai rendah. Dari hasil perhitungan aktivitas belajar pada 30 siswa yang memiliki nilai tinggi dari setiap kelas VIII, dapat diketahui bahwa dari observasi yang dilakukan peneliti diperoleh rata-rata keseluruhan skor sebanyak 38,09 dengan persentase keseluruhan skor sebesar $70,54 \%$. Pada 30 siswa yang memiliki nilai sedang berdasarkan hasil observasi yang peneliti lakukan diperoleh rata-rata keseluruhan skor sebanyak 35,41 dengan persentase keseluruhan skor sebesar $65,57 \%$. Sedangkan pada 30 siswa yang memiliki nilai rendah berdasarkan hasil observasi yang peneliti lakukan diperoleh rata-rata keseluruhan skor sebanyak 32,44 dengan persentase keseluruhan skor sebesar 60,08\%. Hal ini menunjukkan bahwa pelaksanaan aktivitas belajar siswa termasuk dalam kategori baik. Karena dari empat kali observasi yang peneliti lakukan sudah sesuai dengan karakteristik pendekatan SCL meskipun beberapa indikator belum dapat dicapai siswa secara maksimal.

Pendekatan SCL menempatkan siswa sebagai pusat dari proses pembelajaran sebab siswa yang berperan aktif dengan membiasakan siswa dalam mengemukakan pendapat dan merumuskan pertanyaan serta aktif secara mandiri untuk mencari pengetahuannya sendiri. Hal senada juga disampaikan oleh Kain (dalam prasetya, 2013) yang menyatakan bahwa, pembelajaran berpusat pada siswa merupakan pendekatan yang mengharuskan berbagai pengetahuan 
dibangun melalui kegiatan aktif siswa dalam beragam aktivitas. Melalui penerapan pembelajaran yang berpusat pada siswa, maka siswa diharapkan dapat berpartisipasi secara aktif, selalu ditantang untuk memiliki daya kritis, mampu menganalisa dan dapat memecahkan masalahnya sendiri (Karsen, 2008). Guru IPA berperan sebagai fasilitator yang memfasilitasi apa yang diperlukan dalam pembelajaran dan membuat siswa terus aktif selama proses pembelajaran dengan memilih model pembelajaran yang dipadukan dengan pendekatan student centered learning seperti model kooperatif learning, discovery learning, dan problem based learning. Tahap evaluasi pembelajaran IPA dilakukan guru selama proses pembelajaran berlangsung dengan melihat dan menilai sikap (afektif), pengetahuan (kognitif), dan keterampilan (psikomotor) siswa sehingga guru mampu memantau perkembangan belajar siswa dengan berharap agar pelaksanaan evaluasi dapat berjalan dengan optimal. Penilaian untuk kompetensi sikap, pengetahuan dan keterampilan menggunakan skala 100.

Selama guru menerapkan

pendekatan SCL di dalam proses

pembelajaran terkadang saat

pelaksanaannya di kelas belum sepenuhnya dapat diterapkan. Ada beberapa kendala yang dialami guru dan siswa dalam menerapkan pembelajaran berpusat pada siswa (student centered) meskipun siswa sudah memahami materi yang disampaikan guru sebelumnya, pertama, guru dihadapkan pada banyaknya kendala baik itu dari sikap siswa dan kemampuan siswa yang berbeda-beda pada setiap kelas. Sejalan dengan itu, kepala sekolah juga mengatakan bahwa apa yang diharapkan tidak sesuai dengan kenyataan di lapangan. Orientasi pembelajaran dari pendekatan teacher centered ke student centered learning tentu ada hambatan-hambatannya dari sumber daya siswa itu sendiri, sumber daya yang masuk masih sangat kurang sehingga untuk menerapkan pendekatan ini masih belum bisa sepenuhnya dapat diterapkan. Dengan kemampuan siswa yang bervariasi ini diperlukan kejelian guru dalam menggunakan metode yang cocok diterapkan di kelas yang berbeda sehingga RPP yang dibuat guru tidak seragam, mungkin pendekatan SCL dapat diterapkan di kelas atas namun untuk kelas bawah belum tentu sepenuhnya dapat di-terapkan. Kedua, keterbatasan sumber informasi/referensi yang dimiliki oleh siswa seperti buku pegangan IPA kelas VIII edisi revisi kurikulum 2013, dari banyaknya siswa kelas VIII yang ada tidak semua mendapatkan buku pegangan IPA tersebut. Ketiga, proses penilaian yang mesti dilakukan oleh guru banyak, ini dianggap memberatkan guru untuk melaksanakannya sehingga guru merasa terbebani. Guru tidak bisa sekaligus melakukan penilaian sikap, pengetahuan dan keterampilan dalam satu kali pertemuan dengan jumlah yang banyak dalam satu kelas. Penilaian dilakukan secara berkesinambungan untuk menilai siswa, mungkin hari ini guru akan menilai sikap siswa dan pertemuan selanjutnya guru akan menilai kognitif siswa. Kemudian terbatasnya sarana fasilitas sekolah yang dapat menunjang proses pembelajaran seperti kurangnya LCD proyektor, dari banyaknya kelas yang ada hanya terpasang beberapa LCD dari kelas tersebut, namun jaringan wifi internet sudah bisa diakses sampai keseluruhan ruangan dan areal sekolah. Kendala lainnya saat proses pembelajaran pada tahap mengumpulkan informasi atau data serta mengolah informasi terkadang ada beberapa siswa tidak mau bekerjasama dan hanya menunggu hasil pekerjaan teman kelompoknya.

Guru IPA selalu berusaha untuk melakukan berbagai upaya dalam mengatasi kendala yang ditemui selama kegiatan pembelajaran. Dalam mengatasi terbatas-nya referensi, guru mengarahkan siswa untuk melakukan kegiatan literasi ke perpustakaan sekolah mencari buku-buku yang memiliki keterkaitan dengan materi IPA yang akan dipelajari. Dan bisa mencari sumber informasi dari internet untuk menambah pengetahuan siswa. Selain itu, guru memberikan tugas untuk mencari materi yang akan dibahas pada pertemuan selanjutnya agar mememperkaya wawasan pengetahuan siswa dan dapat melengkapi materi yang ada di LKS yang dirasa masih 
kurang padat materinya. Pada penilaian guru memanfaatkan waktu pada saat pelaksanaan pembelajaran berlangsung. Guru memberikan arahan kepada siswa agar sering membaca buku yang terkait dengan materi dan mengakses internet untuk menggali informasi yang ada sebanyak-banyaknya agar wawasan pengetahuan siswa dapat berkembang.

\section{Faktor-Faktor yang Memengaruhi Implementasi Pendekatan SCL}

Pelaksanaan pembelajaran dengan mengimplementasikan pendekatan SCL di SMP Negeri 4 Singaraja belum sepenuhnya dapat diterapkan, hal ini disebabkan oleh beberapa faktor. Beberapa faktor tersebut, diantaranya kemampuan guru dan sarana prasarana belajar.

1) Ditinjau dari kemampuan guru

Berdasarkan observasi terhadap guru model saat mengimplementasikan pendekatan SCL selama proses pembelajaran guru kurang melakukan variasi dalam kegiatan pembelajaran sehingga siswa merasa bosan dengan pembelajaran yang dilakukan oleh guru model. Hal ini sesuai dengan hasil observasi pelaksanaan pembelajaran, dimana kegiatan pembelajar-an yang dilakukan guru model hampir sama disetiap pertemuan. Padahal kualitas pengajaran di sekolah sangat ditentukan oleh guru, sebagaimana dikemukakan oleh Wina Sanjaya (2006) yang menyatakan bahwa, guru adalah komponen yang sangat menentukan dalam implementasi suatu strategi pembelajaran. Kemampuan guru model dalam penguasaan kelas juga terlihat masih kurang dikarenakan pada saat siswa di kelas ribut guru model tidak memarahi mereka, guru model hanya menegur siswa secara halus dan hal tersebut tentu saja tidak berlangsung lama karena beberapa saat kemudian siswa mulai ribut kembali.

Guru model terlihat belum dapat mengubah pola pikirnya bahwa bukan guru yang selalu menjadi pusat belajar bagi siswa tetapi seharusnya pada implementasi pendekatan SCL ini siswa yang harus lebih aktif di kelas, siswa yang harus dapat memproses informasi yang sudah dikumpulkan dan mendorong kemampuan berpikir dalam menyimpulkan. Sehingga guru diharapkan memberi kesempatan kepada siswa untuk mengkomunikasikan apa yang telah mereka pelajari, menyampaikan hasil pengamatan dan memberi ke-simpulan berdasarkan hasil analisis secara lisan, dan tertulis.

2) Ditinjau dari sarana prasarana belajar

Roestiyah (dalam wahono, 2014) menyatakan bahwa, sarana belajar adalah peralatan belajar yang dibutuhkan dalam belajar agar pencapaian tujuan belajar dapat berjalan dengan lancar, teratur, efektif, dan efisien. Dengan memanfaatkan sarana belajar yang baik akan mempermudah siswa untuk melakukan aktivitas belajar sehingga siswa antusias dalam belajar. Sebaliknya, dengan kurangnya sarana pembelajaran akan berdampak pada kurang antusias dan ketertarikan siswa dalam belajar. Pernyataan tersebut sesuai dengan pendapat dari Dalyono (2001) yang menyatakan bahwa, kelengkapan fasilitas belajar akan membantu siswa dalam belajar, dan kurangnya alat-alat atau fasilitas belajar akan menghambat kemajuan belajarnya.

Berdasarkan temuan hasil wawancara dengan guru model terkait faktor-faktor yang memengaruhi implementasi pendekatan SCL, sesuai dengan pernyataan yang disampaikan guru model bahwa masih terbatasnya sarana fasilitas sekolah dalam menunjang proses pembelajaran salah satunya kurangnya ketersediaan LCD proyektor, dari banyaknya kelas yang ada hanya terpasang beberapa LCD dari kelas tersebut. Belum tersedianya LCD ini menyebabkan guru hanya bisa mengajar secara konvensional menggunakan papan tulis, dan guru mengalami kesulitan dalam melakukan variasi mengajar. Kurangnya variasi mengajar membuat siswa menganggap pembelajaran monoton, membosankan dan siswa kurang bersemangat, akibatnya pelajaran yang disampaikan tidak diterima dengan baik oleh siswa. Dan masih terbatasnya buku pelajaran yang wajib digunakan sebagai sumber pegangan bagi siswa untuk belajar. 


\section{Relevansi Pendekatan SCL terhadap Hasil Belajar}

Berdasarkan observasi yang dilakukan pada siswa, baik observasi terhadap hasil belajar IPA maupun observasi pembelajaran di kelas. Hasil observasi awal menunjukkan bahwa suasana pembelajaran di kelas masih terdapat kelemahan. Pada proses pembelajaran IPA di kelas tersebut, terkadang guru masih menerapkan metode pembelajaran yang berpusat pada guru dimana proses pembelajaran tersebut guru yang masih berperan aktif dan siswa tampak hanya mendengarkan dan mencatat materi yang diberikan oleh guru. Bahkan ada beberapa siswa yang tidak fokus mengikuti pembelajaran sampai akhir. Pembelajaran berpusat pada guru sering menghambat siswa dalam membangun kompetensi, baik pengetahuan maupun keterampilan, lebih-lebih dalam pengembangan nilai-nilai dasar untuk berpikir dan bertindak (Santyasa, 2012). Jika pembelajaran cenderung berpusat pada guru, maka pembelajaran tidak lagi menjadi ajang pembudayaan dan pemberdayaan siswa dalam praktik pendidikan. Dengan kata lain, pembelajaran tidak tepat lagi menerapkan pendekatan teacher centered namun harus bergeser menuju pendekatan student centered learning (SCL). Santyasa (2012) menyatakan bahwa, SCL menyediakan peluang pemberdayaan potensi diri siswa secara optimal untuk lebih bertanggung jawab pada proses dan hasil belajarnya.

Berdasarkan studi hasil belajar siswa berupa nilai raport 90 siswa yang masingmasing terdiri dari 30 siswa yang memiliki nilai tinggi, 30 siswa yang memiliki nilai sedang dan 30 siswa yang memiliki nilai rendah pada mata pelajaran IPA pada semester gasal tahun ajaran 2016-2017. Dari nilai hasil belajar IPA 90 siswa tersebut selanjutnya dibuat tabel distribusi frekuensi hasil belajar IPA sebagai berikut.

Tabel 4.3 Distribusi frekuensi hasil belajar IPA

\begin{tabular}{cccc}
\hline $\begin{array}{c}\text { Rentangan } \\
\text { Nilai }\end{array}$ & Frekuensi & $\%$ & Kategori \\
$\geq 80$ & 34 & 37,78 & Sangat \\
\hline
\end{tabular}

\begin{tabular}{|c|c|c|c|}
\hline $60-79$ & 56 & 62,22 & $\begin{array}{l}\text { tinggi } \\
\text { Tinggi }\end{array}$ \\
\hline $40-59$ & - & 0 & $\begin{array}{l}\text { Sangat } \\
\text { rendah }\end{array}$ \\
\hline $20-39$ & - & 0 & $\begin{array}{l}\text { Sangat } \\
\text { rendah }\end{array}$ \\
\hline$<20$ & - & 0 & $\begin{array}{l}\text { Sangat } \\
\text { rendah }\end{array}$ \\
\hline Jumlah & 90 & 100 & $\begin{array}{l}\text { Sangat } \\
\text { rendah }\end{array}$ \\
\hline
\end{tabular}

Berdasarkan distribusi frekuensi hasil belajar IPA siswa di atas dapat digambarkan grafik sebagai berikut.

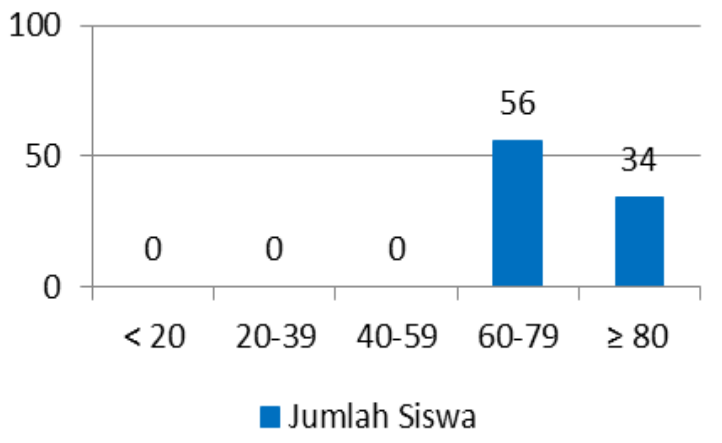

Gambar 4.1 $\begin{gathered}\text { Distribusi frekuensi hasil } \\ \text { belajar IPA }\end{gathered}$

Berdasarkan tabel dan grafik distribusi frekuensi hasil belajar IPA siswa dapat diketahui bahwa dari 90 siswa ada 34 siswa yang memperoleh rentangan nilai $\geq$ 80 dengan persentase $37,78 \%$ yang berkategori sangat tinggi, ada 56 siswa yang memperoleh rentangan nilai 60-79 dengan persentase $62,22 \%$ yang berkategori tinggi.

Berdasarkan data tersebut, dapat diperoleh perhitungan hasil belajar IPA ditinjau dari nilai raport $(x=79)$ yang berada pada rentangan nilai 60-79. Dari data tersebut siswa dapat dikatakan tuntas dalam mengikuti pembelajaran IPA dan data tersebut menunjukkan bahwa hasil belajar IPA siswa kelas VIII SMP Negeri 4 Singaraja berkategori tinggi.

\section{SIMPULAN DAN SARAN}

Berdasarkan hasil penelitian dan pembahasan di atas, dapat disimpulkan sebagai berikut.

1. Implementasi pendekatan SCL dalam pembelajaran IPA di SMP Negeri 4 Singaraja termasuk dalam kategori baik 
meskipun dalam penerapannya belum sepenuhnya dapat dilaksanakan. Ini ditunjukkan dari indikator setiap aspek yang sudah menyesuaikan dengan karakteristik pendekatan SCLmeskipun beberapa indikator belum maksimal dilakukan oleh guru.

2. Faktor yang memengaruhi implementasi pendekatan SCL adalah kemampuan guru dan sarana prasarana belajar.

3. Pembelajaran dengan menggunakan pendekatan SCL berhubungan erat dengan hasil belajar siswa pada pelajaran IPA.

Berdasarkan hasil penelitian di atas, dapat diajukan saran sebagai berikut.

1. Dalam pelaksanaan pembelajaran guru harus lebih optimal melaksanakan pembelajaran dengan berbasis pendekatan SCL yang memusatkan siswa sebagai tokoh aktif serta menggunakan berbagi metode pembelajaran inovatif sehingga proses pembelajaran yang dilakukan guru bervariasi dan tidak monoton.

2. Pelaksanaan pembelajaran dengan menggunakan pendekatan SCL diharapkan mampu meningkatkan aktivitas belajar siswa yang akan berdampak pada hasil belajar yang diperoleh.

\section{DAFTAR PUSTAKA}

Badan Standar Nasional Pendidikan. 2006. Standar Kompetensi dan Kompetensi Dasar SMP/MTs. Jakarta: Depdiknas

Balitbang. 2011. Hasil Survei TIMSS: 2011. Trends Internasional Mathematics and Scince Study. US: TIMSS and PIRLS International Study Center

Dalyono, M. (2001). Psikologi Pendidikan. Jakarta: Rineka Cipta.

Depdikbud. 1996. Program Pembelajaran Terpadu D-II PGSD. Jakarta: Depdikbud

Isjoni. 2007. Cooperative Learning: Efektifitas Pembelajaran Kelompok. Bandung: Alfabeta

Karsen. 2008. "Karakteristik Pembelajaran Student Centered Learning". Tersedia pada http://www.psychologymania.com/201 3/01/karakteristik-pembelajaran- student.html. (diakses pada tanggal 28 Desember 2016)

OECD. 2014. PISA 2012 Result: What Student Know and Can Do. Canada: OECD

Peraturan Menteri Pendidikan dan kebudayaan Nomor 65 Tahun 2013 tentang komponen RPP. Jakarta: Depdiknas

Peraturan Menteri Pendidikan dan kebudayaan Nomor 81 A Tahun 2013 tentang Implementasi Kurikulum 2013. Jakarta: Depdiknas

Peraturan Menteri Pendidikan dan kebudayaan No.103 Tahun 2014 tentang Pembelajaran Pada Pendidikan Dasar dan Pendidikan Menengah. Jakarta: Depdiknas

Prasetya, S P. 2014. Memfasilitasi Pembelajaran Berpusat pada Siswa. Jurusan Pendidikan Geografi Unesa. Jurnal Geografi, Volume 12, Nomor 1 (hlm. 1-12)

Santyasa, I W. 2015. Validasi Dan Implementasi Model-Model Student Centered Learning Untuk Meningkatkan Penalaran Dan Karakter Siswa Sekolah Menengah Atas. Jurusan Teknologi Pembelajaran Program Pascasarjana Universitas Pendidikan Ganesha, Singaraja. Jurnal Pendidikan Indonesia, Volume 4, Nomor 1 (hlm. 512-527)

Sugiyono. 2015. Metode Penelitian Pendidikan. Bandung: Alfabeta

Susanto, A. 2013. Teori Belajar dan Pembelajaran di Sekolah Dasar. Jakarta: Prenadamedia Group

Wahono. 2014. Kualitas Pembelajaran Siswa SMK Ditinjau dari Fasilitas Belajar. Jurnal IImiah Guru. Nomor 1 (hlm. 66-71) 